\title{
Black obsidian procurement strategies and circulation along the northern coast of the Santa Cruz Province (Argentine Patagonia): human mobility and interaction
}

\author{
Pablo Ambrústolo ${ }^{1}$
}

1. CONICET - División Arqueología, Facultad de Ciencias Naturales y Museo, Universidad Nacional de La Plata, Museo de La Plata. Paseo del bosque s/n (1900). La Plata, Argentina. Email: pambrustolo@hotmail.com

\begin{abstract}
:
In this article, we examine the strategies behind the acquisition and reduction of black obsidian found in rock shelters and shell middens from the north coast of the Santa Cruz Province, in Argentine Patagonia. Geochemical analyses performed on black obsidian artifacts from this area posit the longdistance circulation of this raw material given its source at Pampa del Asador, located approximately $400 \mathrm{~km}$ to the west. In a previous article, we suggested that evidence for the initial knapping of obsidian pebbles, added to the identification of artifacts with high cortex percentage, implied that obtaining pieces of said raw material would have been based on pebble morphologies. Here we expand on this proposal, contending that this was the case at least for Late Holocene occupational contexts.

During the Middle Holocene an exceptionally low representation of very small-sized debris without cortical reserve was observed; cores and tools were not registered. Knapping activities related to intermediate technical steps in the framework of core reduction and blank production were evidenced, including small and very small flakes as well as bifacial preforms. We inferred that obsidian pieces probably entered into these Middle Holocene sites as part of personal toolkits, cores and bifacial artifacts without cortex, within the framework of exploratory incursions into the area.

For the Late Holocene occupations, taking into consideration the presence of obsidian pebbles, of similar dimensions to those registered at the source itself, we suggest that their procurement would have occurred through various mechanisms, such as the establishment and strengthening of social relations within the context of mobility circuits that would have linked the coast to the interior, among other factors.
\end{abstract}

Keywords: obsidian; procurement; exploitation; hunter gatherers; human mobility; Patagonia.

\section{Introduction}

In central-southern Patagonia, three obsidian sources have so far been recorded, these are in the western portion of the region. These sources have different varieties of obsidian (Stern 2018). Most of the black obsidian artifacts that have been recorded in surface and stratigraphic contexts at regional level come from the Pampa del Asador (PDA) source, located in the central- 
western region of the Santa Cruz Province (Figure 1) (Belardi et al. 2006; Espinosa \& Goñi 1999; Stern 1999; 2018; among others). The transport and exchange of nodules of this raw material in Patagonia was proposed by scholars on the basis of evidence obtained from sites located at varying distances from PDA (these include, among others, Ambrústolo et al. 2012; Civalero \& Franco 2003; Cueto et al. 2016; 2018; Gómez Otero \& Stern 2005; Hermo 2008: 436; Molinari \& Espinosa 1999).

XRF (X-ray fluorescence), ICP-MS (Inductively Coupled Plasma Mass Spectrometry) and NAA (Neutron Activation Analysis) analyses conducted on 56 obsidian artifacts and pebbles recorded from the north coast of the Santa Cruz Province (Figure 1) indicate that this raw material came from Pampa del Asador, located ca. $400 \mathrm{~km}$ to the west of these sites (Figure 1). These analyses yielded three geochemical types of obsidian, PDAI, PDAII and PDAIIIb (Ambrústolo et al. 2012; Nami et al. 2017). In this context, we proposed that the black obsidian recorded in the Deseado River Lower Basin area (Figure 1) had been acquired through the exchange of pebbles with groups from the interior (Ambrústolo et al. 2012). We formulated this hypothesis given the relatively high frequency of black obsidian artifacts with traces of pebble cortex recorded, among other variables (Ambrústolo et al. 2012).

Archaeological studies carried out along the northern coast of the Santa Cruz Province, Argentina, support the notion of an intensive, redundant and variable exploitation of coastal spaces and resources by human hunter-gatherer groups, mainly during the Late Holocene in the Deseado River Lower Basin (Hammond 2015: 518; Zubimendi et al. 2015; Zubimendi 2019). The most frequently identified archaeological sites were open-air ones: shell middens on dunes with lithics, animal bones, and malacological remains (Hammond 2015: 535). However, occupations of rock shelters located at differing distances from the coast have also been identified (Ambrústolo et al. 2011; Ambrústolo \& Ciampagna 2015). The spatial distribution of the sites suggests a structured use of the environment, mainly linked to the availability of mollusc banks and pinniped colonies in the vicinity of certain coastal areas (Zubimendi et al. 2011).

The Deseado River Lower Basin has a highly variable availability of lithic raw materials. Rocks are available from primary and secondary sources, with local and non-local siliceous rocks of excellent knapping quality being the commonest lithic raw material recorded. Likewise, we also observed the use of low-energy expedient strategies in the exploitation of some immediately available rocks such as basalt and rhyolite (Ambrústolo et al. 2015). In general terms, debitage dominates the lithic assemblages recorded at rock shelters and shell middens of the study area. Cores and tools were identified in low frequencies, less than $10 \%$. Among flaking by-products, there was a predominance of small (20-40 mm), and very smallsized $(<20 \mathrm{~mm})$ flakes. There were also low proportions of primary and secondary flakes, suggesting a low-level of initial flaking activities at the sites. The lithic record from the sites suggests the implementation of tasks related to intermediate and, to a lesser extent, final knapping stages. In the samples analysed, a significant variability in raw materials was observed, although chert and translucent chalcedony were the most represented rocks (more than $80 \%$ ). Aside from some chert varieties, all the identified rocks were locally available, being mostly accessible from secondary sources (Ambrústolo et al. 2015). Among the tools, chert was the most frequently utilised raw material. The most commonly represented tools were scrapers, followed to a lesser extent by retouched flakes, bifacial artifacts, knives, and denticulates. These were also mostly small-sized artefacts $(20-40 \mathrm{~mm})$.

In this article, we summarise the discussion regarding north-eastern Santa Cruz huntergatherer procurement and circulation strategies of obsidian as a raw material. This discussion is based on the record of black obsidian pebbles which have similar dimensions to those identified at the PDA source. We evaluate, applying a techno-morphological approach, the lithic assemblages from stratigraphic contexts within six rock shelters and four shell middens 
located in the Deseado River Lower Basin area (Figure 1). The results were then analysed and compared against data obtained from neighbouring areas. The ensuring results are presented here, and describe two different periods: ca. 7,000-3,500 years ${ }^{14} \mathrm{C}$ BP and 3,500-1,000 years ${ }^{14} \mathrm{C}$ BP.

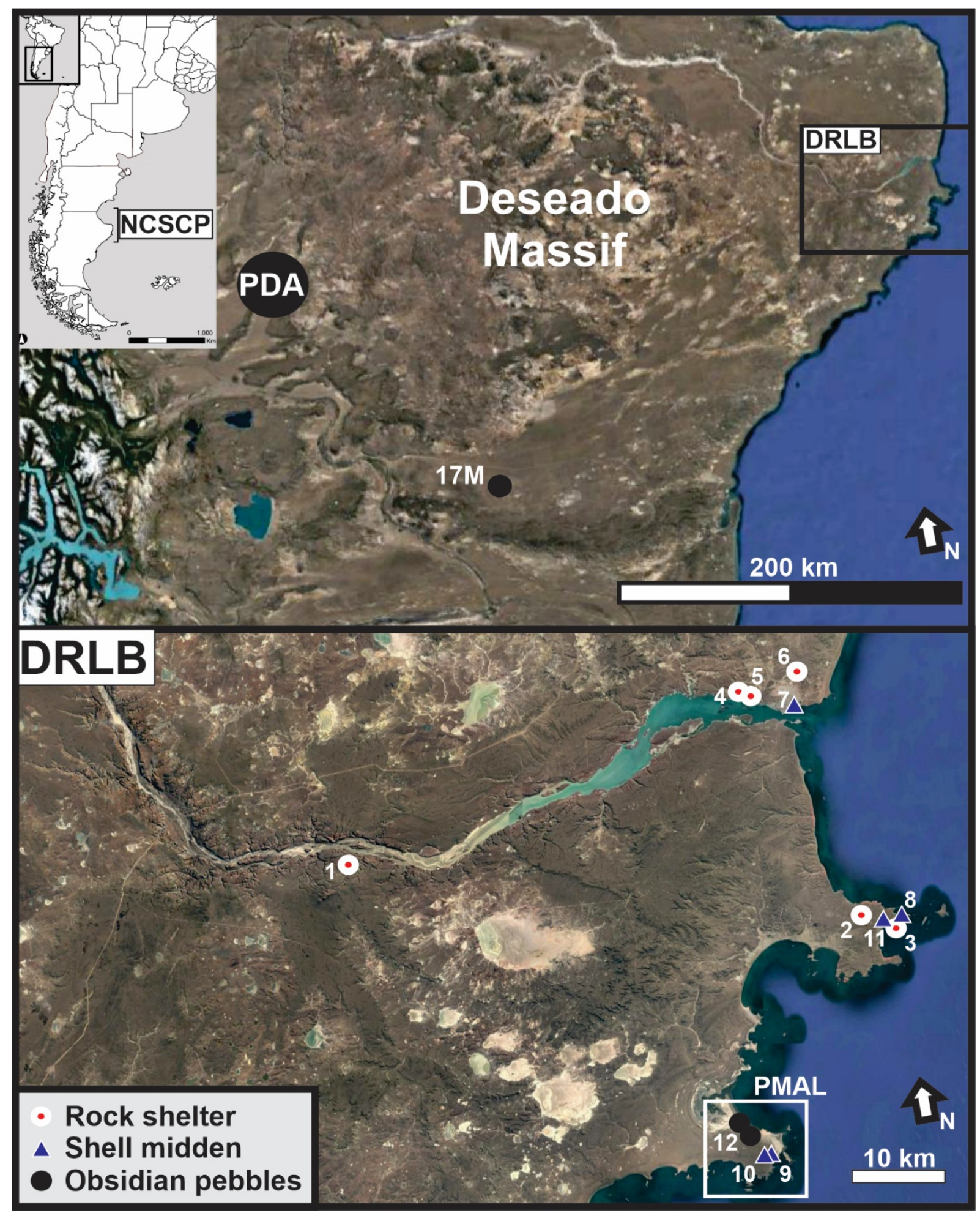

Figure 1. Location of the obsidian sources and archaeological sites containing obsidian. Abbreviations: NCSCP North Coast of Santa Cruz Province; DRLB - Deseado River Lower Basin; PDA - Pampa del Asador; 17M - 17 de Marzo; PMAL - Punta Medanosa Archaeological Locality; 1 - Cueva Marsicano; 2 - Alero El Oriental; 3 - 
Cueva del Negro; 4 - Alero 1; 5 - Alero 4; 6 - Alero El Veneciano 1; 7 - UNPA; 8 - Playa del Negro; 9 - Puesto Baliza 1; 10 - Puesto Baliza 2; 11 - La Lobería; 12 - La Señal.

\subsection{Pampa del Asador source area}

The Pampa del Asador source is located in the centre-west area of the Santa Cruz Province (Figure 1). It was initially defined by Espinosa \& Goñi (1999) as a black obsidian procurement area exploited at a regional scale. Belardi et al. (2006) provides a detailed description of the geology and geomorphology of the area. They indicate that PDA is a large geoform roughly 80 $\mathrm{km}$ in length in a northeast to southwest direction, and with an average width of $15 \mathrm{~km}$. PDA is composed of sedimentary deposits of fluvioglacial origin formed into flatlands; these deposits are of a sandy to sandy-silty matrix including gravels of varying sizes. The fluvioglacial origin is what characterises PDA as a secondary source (Nami 1992).

The first studies and discussions concerning the characteristics of the obsidian pebbles present in PDA, also found in nearby archaeological contexts, was provided by Espinosa \& Goñi (1999). The authors recorded the size of the pebbles, the quantity and variety of artifacts, and the presence of cortex on the flakes. The maximum dimensions of the pebbles were evaluated according to a predetermined scale: small (up to $5 \mathrm{~cm}$ ), medium (between 5.1 and 10 $\mathrm{cm}$ ), and large (more than $10 \mathrm{~cm}$ ) (Espinosa \& Goñi 1999). The authors mainly identified pebbles and flakes -with and without cortex- of medium and small dimensions. Some of the samples obtained were geochemically analysed and six types of obsidian were recognized: PDAI, PDAIIa and b, PDAIIIa, b and c (Stern 1999). Belardi et al. (2006), based on sampling carried out at the foot of the Musters site, that located approximately at the centre of the obsidian distribution in PDA, were the more common pebble sizes present in accordance to the Espinosa \& Goñi scale. This sampling reveals that most of the pebbles were small $(n=23 ; 88 \%)$ or medium ( $\mathrm{n}=3 ; 12 \%)$, among the latter they recorded an average length of $5.6 \mathrm{~cm}$.

In a recent paper, Franco et al. (2017) presented data concerning the existence of a "distal secondary source" known as 17 de Marzo of Pampa del Asador. In a small area to the south of the Deseado Massif (17M; Figure 1), they identified 25 black obsidian pebbles within fluvioglacial deposits. They undertook geochemical analysis on eight pebbles and identified four varieties of PDA obsidian (PDAI, PDAII, PDAIIIa, PDAIIIb and PDAIIIc). The source is at a linear distance of $c a .170 \mathrm{~km}$ from Pampa del Asador and 250-290 km from the Deseado River Lower Basin sites. The pebbles were small, with a maximum length of between 16 and $48 \mathrm{~mm}$. The researchers argued that the procurement and exploitation of these pebbles could have been carried out locally, within the framework of embedded strategies (sensu Binford 1979).

\subsection{Obsidian exploitation in the north-central region of the Santa Cruz Province}

Molinari \& Espinosa (1999) conducted one of the first systematic regional studies analysing several techno-morphological variables in obsidian artifacts from the Thierauf Collection. These are pieces that were collected unsystematically from 340 archaeological sites, covering a wide spatial range within the Santa Cruz Province. The authors considered Pampa del Asador as the only known source of obsidian for Santa Cruz. They also observed that the distribution of black obsidian artifacts covered all the environmental zones of Patagonia, covering the precordillera, central plateaus and coast.

Within this context, they hypothesised that obsidian procurement was the product of large displacements or exchange mechanisms (Molinari \& Espinosa 1999). They assessed the size and cortex proportion of the pieces as direct indicators in the analysis of the relationship between the presence and distribution of these artifacts, their state of conservation, and distance to the source. They identified 329 obsidian artifacts, most of them $(n=197 ; 59.9 \%)$ originating 
in what they termed the "Precordillera" zone. To a lesser extent, they recorded artifacts from the "Central Plateaus" ( $n=100 ; 30.4 \%)$ and the "Coast" $(n=31 ; 9.7 \%)$. The authors assumed the provenance of obsidian as coming from PDA, based primarily on the fact that it was the only source detected to date (Stern 1999), they did not undertake geochemical studies. Insofar as the dimensions and presence of cortical reserve was concerned, they observed a decreasing trend directly proportional to an increase in the distance from PDA. In general terms, this fits into the fall-off distribution model (contrast with Renfrew 1977).

Several studies have highlighted the existence of variations in the techno-morphological characteristics and the absolute and relative frequencies of PDA obsidian pieces based on an increase in the distance of the contexts in regards to the source (Belardi et al. 2006; Cueto et al. 2016; 2018; Franco et al. 2017; Méndez et al. 2018; Pallo \& Borrero 2015; among others). In provenance studies, obsidian artifacts have been chemically analysed to detect trace elements using XRF (X-ray fluorescence) or ICP-MS (Inductively Coupled Plasma Mass Spectrometry) techniques.

In the case of the Deseado Massif (Figure 1), evidence of PDA obsidian exploitation was recorded from the beginning of the occupational sequence (Cueto et al. 2016; 2018; Franco et al. 2017; Hermo 2014; Hermo \& Miotti 2011). These sites date to the Pleistocene-Holocene transition. At these sites, obsidian debitage of very small sizes $(<20 \mathrm{~mm})$ in very low proportions (average $0.41 \%$ ) were recorded, and only a few pieces with limited cortical reserve (25-49\% coverage) were identified (Cueto et al. 2018). During the Early Holocene (ca. 9,500$7,000{ }^{14} \mathrm{C}$ years BP) there was an increase in the relative frequencies of black obsidian (average 9.61\%), with a greater variability of classes and typological groups being represented, including larger pieces. Mainly debitage size was very small $(<20 \mathrm{~mm})$ or small $(20-40 \mathrm{~mm})$. Among the tools, it is worth noting the identification of un-stemmed projectile points at the sites of $\mathrm{El}$ Verano Cueva 1 and La Martita Cueva 4 (Aguerre 2003; Durán et al. 2003).

In La Martita Cueva 4, the black obsidian PDA was also used to make end- and sidescrapers, triangular projectile points, bifacial artifacts and bifacial reduction flakes (Aguerre 2003, Franco et al. 2017). Cueto and collaborators suggest that PDA black obsidian would have been brought into these cave and rock-shelter sites as tools. At Cueva del Minero 1, Cueva de la Ventana, and La Mesada there is little evidence of end-phase work on the tools, represented by retouch and micro-retouch flakes (Cueto et al. 2018). During the period between 7,000 and $3,500{ }^{14} \mathrm{C}$ years $\mathrm{BP}$ there are low relative frequencies of black obsidian artifacts recorded across these sites; on average, when considering the total sample of lithic pieces identified for this period, only 2.62\% PDA black obsidian artifacts were observed. The maximum dimensions of these pieces do not exceed $40 \mathrm{~mm}$ and are comprised mainly of debitage of very small $(<20$ $\mathrm{mm})$ size and, to a lesser extent, small size (20-40 mm). Bifacial thinning flakes, retouch, and micro-retouch flakes (among those produced during the final phase tool manufacture, including re-flaking, retouch, bifacial thinning), were recorded (Cueto et al. 2016; 2018). Very few tools were identified, although a retouched blade was recorded at La Mesada and a unifacial tool was recovered from Cerro Tres Tetas 1 (Cueto et al. 2018). In most contexts cortical reserve was recorded.

During the Late Holocene (3,500-1,000 ${ }^{14} \mathrm{C}$ years BP) there is evidence of exploitation of PDA black obsidian in five rock shelters sites located in the Deseado Massif (Casa del Minero 1, La Gruta 1, Cueva La Hacienda, Cueva Maripe and Cueva Moreno). In general, with respect to the previous chronological time period, there is an increase in the relative frequency of obsidian artifacts (average 8.63\%) recorded at these places. Mainly, debris was identified, represented by flakes and blades (of a standardised size and un-retouched edges). Artefactual variability was observed, for example, among tools from Casa del Minero 1, projectile points, scrapers, and retouch flakes were recorded (Cueto et al. 2018). Among the largest objects, medium-small sized pieces ( $40-60 \mathrm{~mm}$ ) were registered. On most of the occupations, artefacts 
with cortex reserve were identified. Due to this, Hermo \& Miotti (2011) suggested that during the Middle and Late Holocene, PDA black obsidian could have entered the Deseado Massif in pebble-form.

Existing studies (Cueto et al. 2018; Franco et al. 2017; Pallo \& Borrero 2015) confirm that at a regional scale the relative frequency and distribution of PDA black obsidian in centralsouthern Patagonia tends to decrease as the distance from the procurement source increases (Renfrew 1977). In sites relatively close to PDA, up to $c a$. $50 \mathrm{~km}$, proportions greater than $60 \%$ were registered. Variable relative frequencies -between $60 \%$ and $10 \%$ - are recorded up to about $125 \mathrm{~km}$ away; in the Deseado Massif and north of the Santa Cruz River, at ca. 125 and $180 \mathrm{~km}$ of PDA the frequency varies between $13 \%$ and $1 \%$. In the Deseado River Lower Basin, at $c a$. $350 \mathrm{~km}$ from PDA proportions of between 1\% and 5\% were observed. At distances greater than $400 \mathrm{~km}$ contexts with frequencies below 1\% were identified.

Following Borrero (2012), the fact that it is a distribution of artefacts of known origin constitutes a sufficient characteristic for a declination pattern to be fulfilled, a pattern that depends on the distance from the source. Pallo \& Borrero (2015) point out that, at the largescale, the PDA obsidian fall-off point would be below $125 \mathrm{~km}$ from the sector closest to the Pampa del Asador source area. The relative frequencies would reach another threshold $(<15 \%)$ close to $400 \mathrm{~km}$; from there, they argue that the presence of obsidian is very low $(<1 \%)$. Around the first threshold at $c a .125 \mathrm{~km}$ from PDA, that is to say the dividing point between high and low deposition intensity, there is the suggestion that the settlements in this area would have been spatially structured within a typical framework of home ranges, which would not necessarily be directly associated with obtaining obsidian. In this sense, it is worth mentioning that Méndez et al. (2018) identify similar trends for central western Patagonia, where they observe an exponential decrease in the frequencies of obsidians at about 100 linear $\mathrm{km}$ from the sources.

\section{Materials and methods}

Obsidian remains from stratigraphic contexts recorded in rock shelters (Cueva Marsicano, Alero El Oriental, Cueva del Negro, Alero 1, Alero 4 and Alero El Veneciano 1) (Ambrústolo et al. 2011; Ambrústolo \& Ciampagna 2105) and shell middens (Playa del Negro, Puesto Baliza 1, Puesto Baliza 2 and UNPA) were analysed (Hammond 2015: 285). Likewise, the artifacts from surface samplings of two shell middens were also studied (La Lobería and La Señal). The analysed sample consists of 132 obsidian artifacts (See Table 1 and Figure 1).

The occupation chronology was established using radiocarbon dates. In cases where there were no available absolute ages, relative dates were proposed based on the minimum ages assigned to the coastal cords systems in the vicinity of the sites (Zubimendi 2019). As mentioned, based on a chronological criterion, the information was structured around two temporary blocks: ca. 7,000-3,500 years ${ }^{14} \mathrm{C}$ BP and 3,500-1,000 years ${ }^{14} \mathrm{C}$ BP (See Table 1).

During the technological study of obsidian artifacts, their morphological and technical attributes were considered. The traits taken into consideration were: size of the artifacts, type of flakes and tools, and the presence and amount of cortex available. Geochemical analyses were not performed on pieces of the sample studied here, instead the trends obtained from trace element studies on obsidian artifacts previously recorded for the study area were taken as reference (Ambrústolo et al. 2012; Nami et al. 2017). Following Cueto et al. (2016; 2018), the technological analysis involved determining the stage of reduction to which the obsidian remains from the different sites belonged. This approach enabled us to organise the artifacts according to the following technical steps: 1 . Core preparation and initial reduction (decortication), 2. Core reduction and blank production, and 3. Final shaping of tools (reflaking, retouch, bifacial thinning). 
Table $1 .{ }^{14} \mathrm{C}$ dates of analysed sites.

\begin{tabular}{|c|c|c|c|}
\hline Period & Site & Date & References \\
\hline ca. $7,000-3,500$ & Alero & LP-2318: $6,930 \pm 100$ years ${ }^{14} \mathrm{C}$ BP & (Ambrústolo et al. \\
\hline \multirow[t]{8}{*}{ years ${ }^{14} \mathrm{C} \mathrm{BP}$} & El Oriental & LP-2310: $5,860 \pm 90$ years ${ }^{14} \mathrm{C} B P$ & 2011) \\
\hline & & LP-2310: $5,860 \pm 90$ years ${ }^{14} \mathrm{C} B P$ & \\
\hline & & LP-2218: $5,810 \pm 110$ years ${ }^{14} \mathrm{C}$ BP & \\
\hline & & LP-2311: $5,150 \pm 80$ years ${ }^{14} \mathrm{C} \mathrm{BP}$ & \\
\hline & Cueva & AA80415: $6,853 \pm 48$ years ${ }^{14} \mathrm{C}$ BP & (Paunero et al. \\
\hline & Marsicano & AA80414: $6,684 \pm 48$ years ${ }^{14} \mathrm{C}$ BP & 2019) \\
\hline & & LP-3645: 4,670 \pm 100 years ${ }^{14} \mathrm{C}$ BP & \\
\hline & $\begin{array}{c}\text { Alero El } \\
\text { Veneciano } 1\end{array}$ & LP-3652: 3,510 \pm 90 years ${ }^{14} \mathrm{C} B P$ & Unpublished \\
\hline $3,500-1,000$ & Cueva & LP-3633: $3,140 \pm 90$ years ${ }^{14} \mathrm{C} \mathrm{BP}$ & Unpublished \\
\hline \multirow{17}{*}{ years ${ }^{14} \mathrm{C} \mathrm{BP}$} & Marsicano & LP-3630: $2,120 \pm 60$ years ${ }^{14} \mathrm{C} B P$ & \\
\hline & & LP-3642: $1,970 \pm 60$ years ${ }^{14} \mathrm{C} B P$ & \\
\hline & Alero 4 & LP-2762: $2,760 \pm 70$ years ${ }^{14} \mathrm{C} \mathrm{BP}$ & (Ambrústolo \& \\
\hline & & LP-2908: $1,690 \pm 90$ years ${ }^{14} \mathrm{C} \mathrm{BP}$ & Ciampagna 2015) \\
\hline & $\begin{array}{c}\text { Alero El } \\
\text { Veneciano } 1\end{array}$ & LP-3662: $2,310 \pm 80$ years ${ }^{14} \mathrm{C} \mathrm{BP}$ & Unpublished \\
\hline & Alero 1 & undated & \\
\hline & Cueva del & LP-2071: $1,730 \pm 80$ years ${ }^{14} \mathrm{C} B P$ & (Zubimendi et al. \\
\hline & Negro & LP-2320: $1,390 \pm 70$ years ${ }^{14} \mathrm{C} B P$ & 2011) \\
\hline & & LP-2065: $1,340 \pm 60$ years ${ }^{14} \mathrm{C} \mathrm{BP}$ & \\
\hline & & LP-2279: $1,290 \pm 50$ years ${ }^{14} \mathrm{C} B P$ & \\
\hline & & LP-2047: $1,220 \pm 80$ years ${ }^{14} \mathrm{C} \mathrm{BP}$ & \\
\hline & & LP-2290: $1,170 \pm 110$ years ${ }^{14} \mathrm{C}$ BP & \\
\hline & $\begin{array}{l}\text { Alero El } \\
\text { Oriental }\end{array}$ & LP-2267: $1,530 \pm 60$ years ${ }^{14} \mathrm{C} B P$ & $\begin{array}{c}\text { (Ambrústolo et al. } \\
\text { 2011) }\end{array}$ \\
\hline & $\begin{array}{l}\text { Playa del } \\
\text { Negro }\end{array}$ & LP-2682: $1,450 \pm 60$ years ${ }^{14} \mathrm{C} B P$ & $\begin{array}{l}\text { (Hammond } \\
\text { 2015:285) }\end{array}$ \\
\hline & Puesto Baliza 1 & undated & \\
\hline & Puesto Baliza 2 & LP-2732: $1,290 \pm 60$ years ${ }^{14} \mathrm{C} B P$ & \\
\hline & UNPA & LP-2891: $970 \pm 50$ years ${ }^{14} \mathrm{C} B P$ & \\
\hline
\end{tabular}

\section{Results}

For the period $\mathrm{ca}$. 7,000-3,500 ${ }^{14} \mathrm{C}$ years $\mathrm{BP}$ only 10 black obsidian artifacts were registered (Table 2). If the total lithic pieces identified at the three sites presented here are considered $(n=684)$, the average relative frequency of obsidian in this case is $1.46 \%$. All cases were very small-sized debris $(<20 \mathrm{~mm})$ (Table 2$)$. Among the complete pieces $(\mathrm{n}=6 ; 60 \%)$, core reduction flakes $(n=5 ; 83.3 \%)$ and a bifacial thinning flake $(n=1 ; 16.7 \%)$ were identified. These indicate that at these sites the main tasks undertaken were those of core reduction and final shaping of tools. The predominance of lineal platforms $(n=3 ; 50 \%)$ and, to a lesser extent, flat $(n=1 ; 16.7 \%)$, prepared $(n=1 ; 16.7 \%)$, and punctiform $(n=1 ; 16.7 \%)$ platforms, supports the observed trends. No artifacts with cortex reserve were identified, which suggests that core preparation and initial reduction activities were not being carried out at these sites. 
Table 2. Characteristics of obsidian assemblages of the period ca. 7,000-3,500 years ${ }^{14} \mathrm{C}$ BP.

\begin{tabular}{|c|c|c|c|}
\hline \\
\hline \multicolumn{4}{|c|}{ 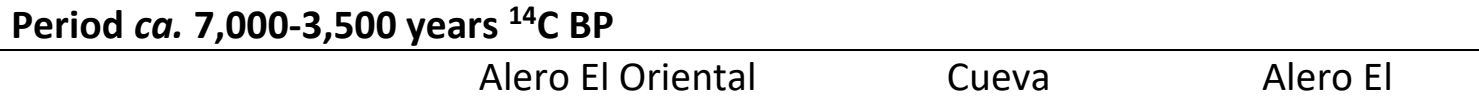 } \\
\hline & & Marsicano & Veneciano 1 \\
\hline Obsidian N (\%) & $6(1.3)$ & $3(1.75)$ & $1(2.7)$ \\
\hline Typological classes & Debitage & Debitage & Debitage \\
\hline Maximum length & $14 \mathrm{~mm}$ & $12 \mathrm{~mm}$ & No data \\
\hline Distance to PDA & \multicolumn{3}{|c|}{ Between ca. 300-350 Km } \\
\hline Cortex & No & No & No \\
\hline
\end{tabular}

Table 3. Characteristics of obsidian assemblages of the period 3,500-1,000 years ${ }^{14} \mathrm{C} \mathrm{BP}$.

\begin{tabular}{|c|c|c|c|c|c|c|}
\hline \multicolumn{7}{|c|}{ Period $3.500-1.000$ years ${ }^{14} \mathrm{C}$ BP } \\
\hline Rock shelter & $\mathrm{CM}$ & A4 & AEV1 & A1 & CDN & AEO \\
\hline Obsidian N (\%) & $4(1.1)$ & $91(4.7)$ & $1(1.9)$ & $4(5.2)$ & $8(1.1)$ & $2(4.2)$ \\
\hline $\begin{array}{l}\text { Typological } \\
\text { classes }\end{array}$ & Deb. & $\begin{array}{l}\text { Deb., } \\
\text { Core, Tool }\end{array}$ & Tool & $\begin{array}{l}\text { Deb., } \\
\text { Tool }\end{array}$ & Deb. & $\begin{array}{l}\text { Deb., } \\
\text { Core }\end{array}$ \\
\hline Maximum length & $23 \mathrm{~mm}$ & $35 \mathrm{~mm}$ & $35 \mathrm{~mm}$ & $19 \mathrm{~mm}$ & $36 \mathrm{~mm}$ & $27 \mathrm{~mm}$ \\
\hline Distance to PDA & \multicolumn{6}{|c|}{ Between ca. $300-350 \mathrm{~km}$} \\
\hline Cortex & Yes & Yes & No & Yes & No & Yes \\
\hline Shell midden & PDN & PB1 & PB2 & UNPA & & \\
\hline Obsidian N (\%) & $4(1.6)$ & $1(1.8)$ & $3(3.75)$ & $4(0.1)$ & & \\
\hline $\begin{array}{l}\text { Typological } \\
\text { classes }\end{array}$ & Deb. & Deb. & Deb. & Deb., Tool & & \\
\hline Maximum length & $20 \mathrm{~mm}$ & $20 \mathrm{~mm}$ & $20 \mathrm{~mm}$ & $40 \mathrm{~mm}$ & & \\
\hline Distance to PDA & \multicolumn{6}{|c|}{ Between ca. $300-350 \mathrm{~km}$} \\
\hline Cortex & No & No & No & No & & \\
\hline
\end{tabular}

The relative frequency of black obsidian artifacts recorded for the period between 3,500 and $1,000{ }^{14} \mathrm{C}$ years BP was slightly higher than that identified for the initial period $(\mathrm{n}=110$; $3.46 \%$ ) (Table 3). There was some variability in the typological classes represented. In addition to the majority of the black obsidian artifacts being identified as debris ( $\mathrm{n}=104$; $94.5 \%)$, tools $(\mathrm{n}=4 ; 3.6 \%)$ and cores $(\mathrm{n}=2 ; 1.8 \%)$ were also recognized (Table 4). Tools were represented by retouched flakes $(n=3 ; 75 \%)$ and a bifacial preform (25\%) (Figure 2c); in all cases they were small in size (20-40 mm) (Table 3). At the La Lobería site (Figure 1), in a surface context, a small projectile point with evidence of resharpening was also recorded (Figure 2e). Debris were mostly flakes ( $\mathrm{n}=94 ; 90.4 \%$ ) and, to a lesser extent, undifferentiated pieces were also identified $(\mathrm{n}=10 ; 9.6 \%)$. Exactly half the flakes were fractured.

Among the complete pieces ( $\mathrm{n}=47 ; 50 \%$ ), the majority were core reduction flake and blank production ( $\mathrm{n}=45 ; 95.7 \%)$. Two pieces $(4.3 \%)$ were related to core preparation and initial reduction tasks (Table 5). Flakes were mostly very small size $(<20 \mathrm{~mm})(\mathrm{n}=39 ; 83 \%)$ and, to a lesser extent, small $(20-40 \mathrm{~mm})(\mathrm{n}=8 ; 17 \%)$ (Table 6). It is interesting to note that among the complete flakes there was a high relative frequency of pieces with cortical reserve $(n=9 ; 19.1 \%)$. In relation to the cortex reserve, the majority had between $25-50 \%(n=5)$ of the cortex reserve, followed by those that had less than $25 \%(n=3)$ and, finally, those that had a coverage of between 50-75\% $(n=1)$ (Table 7). The two identified cores had high cortex proportions, one was very small in size, and the other was small. The latter presented evidence of bipolar flaking (Figure 2b), probably due to its dimensions (23.6 mm x $20.4 \mathrm{~mm}$ x $8.5 \mathrm{~mm}$ ). 
This size was similar to that recorded in the pebbles from the $17 \mathrm{M}$ source (Figure 1), on the southern margin of the Deseado Massif, located ca. $280 \mathrm{~km}$ from the Deseado River Lower Basin. In this sense, is important to highlight that at the La Lobería site (Figure 1), in a surface context, a small core with cortical remains and evidence for bipolar flaking (Figure 2d) was recorded. There were no significant differences in the characteristics of the lithic assemblages identified at rock shelters and shell middens.

Table 4. Typological Structure of the assemblages from each period.

\begin{tabular}{|c|c|c|c|c|}
\hline \multirow[b]{2}{*}{$\begin{array}{l}\text { Typological } \\
\text { Classes }\end{array}$} & \multicolumn{2}{|c|}{ ca. $7,000-3,500$ years ${ }^{14} \mathrm{C} B P$} & \multicolumn{2}{|c|}{$3,500-1,000$ years ${ }^{14} \mathrm{C} B P$} \\
\hline & $\mathrm{N}$ & $\%$ & $\mathrm{~N}$ & $\%$ \\
\hline Debitage & 10 & 100 & 104 & 94.5 \\
\hline Core & - & - & 2 & 1.8 \\
\hline Tool & - & - & 4 & 3.6 \\
\hline Total & 10 & 100 & 110 & 100 \\
\hline
\end{tabular}

Table 5. Artifact frequencies according to reduction stage.

\begin{tabular}{|c|c|c|c|c|}
\hline \multirow[b]{2}{*}{$\begin{array}{l}\text { Reduction } \\
\text { stages }\end{array}$} & \multicolumn{2}{|c|}{ ca. $7,000-3,500$ years ${ }^{14} \mathrm{C} \mathrm{BP}$} & \multicolumn{2}{|c|}{$3,500-1,000$ years ${ }^{14} \mathrm{C} B P$} \\
\hline & $\mathrm{N}$ & $\%$ & $\mathrm{~N}$ & $\%$ \\
\hline Decortication & - & - & 2 & 4.3 \\
\hline $\begin{array}{l}\text { Core } \\
\text { reduction }\end{array}$ & 5 & 83.3 & 45 & 95.7 \\
\hline Final shaping & 1 & 16.7 & - & - \\
\hline Total & 6 & 100 & 47 & 100 \\
\hline
\end{tabular}

Table 6. Size of complete flakes by period.

\begin{tabular}{lllll}
\hline & \multicolumn{2}{c}{ ca. $\mathbf{7 , 0 0 0 - 3 , 5 0 0}$ years ${ }^{14} \mathbf{C}$ BP } & \multicolumn{2}{l}{$\mathbf{3 , 5 0 0 - 1 , 0 0 0}$ years ${ }^{14} \mathbf{C}$ BP } \\
Size & $\mathrm{N}$ & $\%$ & $\mathrm{~N}$ & $\%$ \\
\hline Very small $(<20 \mathrm{~mm})$ & 6 & 100 & 39 & 83 \\
Small $(20-40 \mathrm{~mm})$ & - & - & 8 & 17 \\
Total & 6 & 100 & 47 & 100 \\
\hline
\end{tabular}

Table 7. Amount of cortex in complete flakes by period.

\begin{tabular}{lllll}
\hline & \multicolumn{2}{l}{ ca. $\mathbf{7 , 0 0 0 - 3 , 5 0 0}$ years ${ }^{14} \mathbf{C ~ B P}$} & \multicolumn{2}{l}{$\mathbf{3 , 5 0 0 - 1 , 0 0 0}$ years ${ }^{{ }^{14} \mathbf{C} \text { BP }}$} \\
Cortex & $\mathrm{N}$ & $\%$ & $\mathrm{~N}$ & $\%$ \\
\hline None (0\%) & 6 & 100 & 38 & 80.8 \\
Scarce (1-25\%) & - & - & 3 & 6.4 \\
Partial (25-50\%) & - & - & 5 & 10.6 \\
Abundant (50-75\%) & - & - & 1 & 2.2 \\
Very abundant (+75\%) & - & - & - & - \\
Total & 6 & 100 & 47 & 100 \\
\hline
\end{tabular}




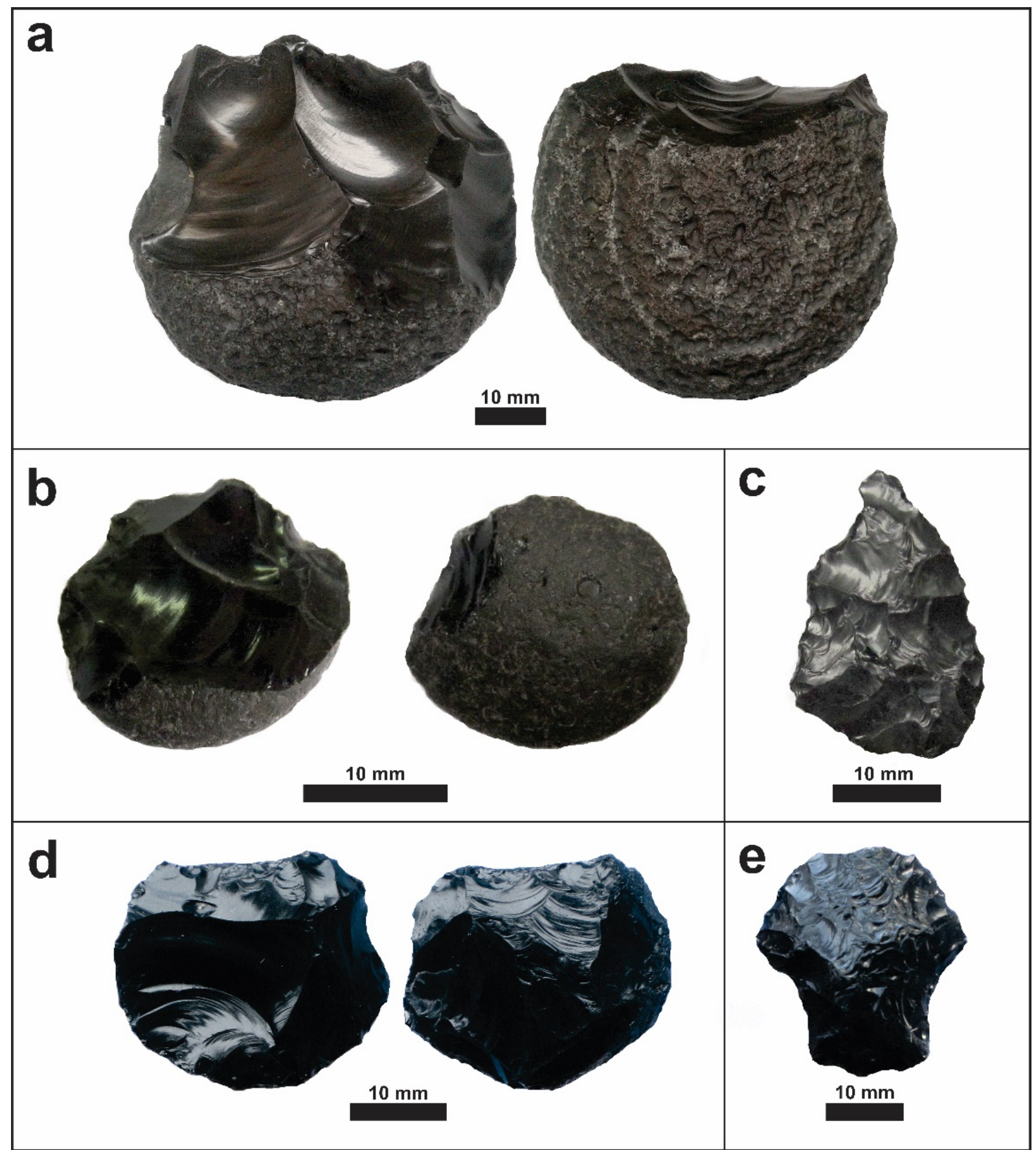

Figure 2. a: Medium-sized obsidian pebble with knapping evidence; b: Small-sized obsidian pebble with evidence of bipolar flaking; c: Obsidian bifacial preform; d: Bipolar core on small obsidian pebble; e: Projectile point.

\subsection{Obsidian pebbles from northeastern Santa Cruz}

As previously mentioned, at the Punta Medanosa Archaeological Site, located ca. $30 \mathrm{~km}$ south of the Deseado River Lower Basin (Figure 1), knapped black obsidian pebbles were identified in surface contexts. These were shell middens located on coastal dunes near the Atlantic coast (Hammond 2015: 28; Zubimendi 2019; among others). The archaeological record is composed basically of lithic, animal bone, and malacological remains. Four black obsidian pebbles were recovered from one site (Table 8; Figure 2). These were pieces with discoidal morphology that presented knapping evidence and had an abundant cortex reserve, more than $75 \%$ of the surface. As can be seen in Table 8 , based on the size ranges proposed by Espinosa \& Goñi (1999) for pebbles recorded near Pampa del Asador, piece d had a maximum 
dimension which assigned it to the small category (up to $5 \mathrm{~cm}$ ), while the remaining objects were all medium pieces (between 5.1-10 cm) (Figure 2a).

Table 8. Black obsidian pebble size

\begin{tabular}{|c|c|c|c|c|}
\hline \multicolumn{5}{|c|}{ Black obsidian pebbles } \\
\hline \multirow[b]{2}{*}{ Sample } & \multicolumn{3}{|c|}{ Dimensions (mm) } & \multirow[t]{2}{*}{ Morphology } \\
\hline & Length & Width & Thickness & \\
\hline a & 57.2 & 52.4 & 26 & Discoidal \\
\hline$b$ & 53 & 43.3 & - & Discoidal \\
\hline c & 50.5 & 46 & - & Discoidal \\
\hline$d$ & 46.6 & 33.1 & - & Discoidal \\
\hline Mean & 51.8 & 43.7 & - & \\
\hline
\end{tabular}

\section{Exploitation of black obsidian along the northeastern Santa Cruz coast: General trends}

In general terms, very low frequencies of black obsidian artifacts were recorded in the Deseado River Lower Basin for the two periods considered here. In both cases, the average proportions did not exceed 3.5\%, and were lower than those identified in the central-southern portion of the Deseado Massif during the same time periods (Cueto et al. 2016; 2018; Franco et al. 2017). In DRLB only a slight increase in frequencies of $2 \%$ was observed between the distinct periods. We consider that the observed trends regarding the strategies of exploitation of black obsidian in both temporal blocks were not related to the sample sizes, which in proportional terms were representative of the variations observed in the lithic assemblages identified for both periods.

During the period $\mathrm{ca}$. 7,000-3,500 ${ }^{14} \mathrm{C}$ years BP an exceedingly low representation of very small size debris without cortical reserve was observed; cores and tools were not identified. Knapping activities related to intermediate technical steps in the framework of core reduction and blank production were evidenced, with probably small and very small sizes, and bifacial preforms (based on the identification of bifacial thinning flakes). From this we inferred the probable entry to the various sites of pieces belonging to personal toolkits with cores and bifacial artifacts without cortex. In black obsidian assemblages from contexts assignable to 3,500-1,000 ${ }^{14} \mathrm{C}$ years BP period, a greater artefactual variability was observed in terms of typological classes represented (debitage, cores and tools).

\section{Discussion and conclusions}

The identification of black obsidian pebbles of similar sizes to those available at PDA constitutes a good material correlate to evaluate these discoveries and the artefacts identified in the context of a discussion regarding the possible procurement strategies in an area very distant from the original source. In this sense, it is important to contrast the expected archaeological traits to determine situations of direct and indirect procurement (Charlin 2009; Civalero \& Franco 2003; Franco 2014; Meltzer 1989; Odell 1996, among others). According to the principles of raw material economy (sensu Odell 1996), for direct procurement scenarios (based on the declination model proposed by Renfrew (1977)) high frequencies of the rock are to be expected. Furthermore, these will present all manufacturing stages and include the presence of cores, high cortex indexes and a generalized raw material use, not restricted to a particular artifact class (Franco 2014).

On the other hand, in indirect procurement contexts, Franco (2014) proposes the existence of two possible scenarios: the exchange of artifacts (usually tools), or raw material exchange 
(pebbles, blanks and cores). In archaeological contexts, the representation of different stages of the manufacture sequence would be expected, although there could be a prevalence of final stages in accordance to the strategies of raw material economy, and would entail the presence of blanks or cores, as well as flakes and artifacts with cortex (Civalero \& Franco 2003; Franco 2014). In both alternatives of indirect procurement, we would expect that the raw material had a low representativeness within the lithic assemblages and that its use would be restricted to certain kinds of tools that were in turn curated (sensu Binford 1979).

Based on the expectations of Franco (2004), in general terms the characteristics of the black obsidian record in the north coast of Santa Cruz which presents artifacts (very small and small, in some cases with cortical reserves) and pebbles (small and medium-sized, similar to those observed at PDA), both at low frequencies, suggests that these contexts could be the result of forms of human transport and interaction not directly associated with exchange in formal terms (Smith et al. 2012) or direct procurement. Formal exchange (Smith et al. 2012) would be linked to reciprocity mechanisms. Based on ethnographic data, the material correlate of this mechanism would be the presence of abundant items outside the area of origin (Kelly 2011). As such, ethnographic studies indicate that hunter-gatherer groups can obtain resources through formal exchange mechanisms motivated by economic issues, and informal exchange whether planned or opportunistic, structured according to the establishment or support of social relationships (Smith et al. 2012: 400). This last option is probably the one that best explains the general characteristics identified in the black obsidian assemblages from the Deseado River Lower Basin during the Early to Late Holocene.

These records of low obsidian frequencies across both periods would not correspond to a systematic pattern of raw material circulation. In line with what Pallo \& Borrero (2015) state, beyond the fact that the assemblages were recorded above the point of fall-off mentioned above, they do not offer clear evidence regarding the interpretation of the data around the implementation of procurement practice mechanisms linked to scheduled or regular exchange systems. Within regional context, obsidian seems to have been systematically provisioned to a relatively small and circular area around PDA (Pallo \& Borrero 2015). In the case of the Deseado River Lower Basin, the procurement and exploitation of PDA black obsidian -for both periods- would have occurred within the framework of human group movements through variable spatial dimensions and mobility ranges which could have included relatively inland areas located near to the coast.

Archaeological data concerning the connections between the coast and inland suggests that mobility would have worked on a spatial scale with a maximum amplitude of $c a .150 \mathrm{~km}$ (Zubimendi \& Ambrústolo 2011). The procurement of black obsidian could have been structured around various non-exclusive mechanisms which might have also been acting simultaneously. For instance, as Pallo \& Borrero (2015) suggest, focusing on population vectors along a west-east direction, situations of people displacement which would have been configured across wide mobility ranges -probably secondary with respect to the source acquisition ranges. In these displacements it is possible that they were able to occasionally visit the coast. Following from this, they suggest the existence of differential transport of limited quantities of artifacts and the consequent incidental deposition of some of them.

This could have occurred within the structure of the Deseado River Lower Basin population and exploration phase during the period $c a$. 7,000-3,500 years ${ }^{14} \mathrm{C} \mathrm{BP}$. However, we consider that the fact that, in late contexts there are re-usable medium-sized obsidian pebbles and artifact classes and typological group variability, would not suggest that these pieces had been discarded within a framework of eventual use, this approach is in line with Cueto et al. (2018).

When considering population movements in a west-east direction and vice versa, obsidian procurement could have been structured around the implementation of visit mechanisms and 
extended home ranges. Such strategies would involve the movement of people without the specific purpose of carrying out, for example, exchange of goods (Pallo \& Borrero 2015). As such, procurement could have been structured around informal exchange mechanisms (Smith et al. 2012), which could have been carried out within the framework of opportunistic or embedded situations (sensu Binford 1979) depending on territorial or annual movements with the purpose of establishing or strengthening social relations at the point of meeting. In this context, it is worth mentioning that stable isotope studies carried out on human skeletal remains to evaluate the diets of populations that occupied the Deseado River Lower Basin in the past show a clear trend towards the identification of mixed diets during the Middle and Late Holocene (Moreno et al. 2011; Zilio et al. 2018). The authors argue that this trend could be explained by a seasonal use of the coast within the framework of a complementary exploitation between the inland and coastal areas. In turn, this mobility scenario could have favoured the circulation of obsidian pieces as high-value goods based on the social aesthetic significance materialised in the rock (Hermo 2008: 438; Hermo \& Miotti 2011).

\section{Acknowledgements}

We thank the anonymous reviewers and editors of the manuscript for their valuable suggestions. We also thank all members of our research team, who have participated in the field work. We extend our gratitude to the Mario Brozoski Museum and the Municipality of Puerto Deseado. The CONICET, FONCYT and UNLP funded this research.

\section{References}

Aguerre, A. M. 2003, La Martita: Ocupaciones de 8000 años en la Cueva 4. In Arqueología y Paleoambiente en la Patagonia Santacruceña Argentina (Aguerre, A.M., Ed.), Ediciones del Autor, Buenos Aires: p. 29-61. (in Spanish) ("The Martita: 8000 years of occupations in Cave 4")

Ambrústolo, P. \& Ciampagna, M. L. 2015, Alero 4 rock shelter, north coast of Deseado estuary (Patagonia, Argentina): Hunter-gatherer mobility strategies during the Late Holocene. Quaternary International, 373: 17-25. doi:10.1016/j.quaint.2014.10.035

Ambrústolo, P., Zubimendi, M. A., Castro, A., Ciampagna, L., Hammond, H., Zilio, L. \& Mazzitelli, L. 2015, Fuentes de materias primas líticas en la costa norte de Santa Cruz (Patagonia argentina): el caso del sur de la ría Deseado. Intersecciones en Antropología, Special Volume 2: 51-60. (in Spanish) ("Sources of lithic raw materials on the north coast of Santa Cruz (Argentine Patagonia): the case of the south of the Deseado estuary)

Ambrústolo, P., Zubimendi, M. A., Ciampagna, L. \& Trola, V. 2011, Alero El Oriental: Evidencias de las primeras ocupaciones de la Costa Norte de Santa Cruz (Patagonia, Argentina). Revista Werken, 14: 9-22. (in Spanish) ("Evidences of the first occupations of the North Coast of Santa Cruz, Argentinian Patagonia”)

Ambrústolo, P., Zubimendi, M. A. \& Stern, C. 2012, Explotación de obsidiana negra en la costa norte de Santa Cruz (Patagonia argentina). Cazadores Recolectores del Cono Sur, 6: 7786. (in Spanish) ("Exploitation of black obsidian on the north coast of Santa Cruz (Patagonia Argentina")

Belardi, J. B., Tiberi, P., Stern, C. \& Súnico, A. 2006, Al este del Cerro Pampa: ampliación del área de disponibilidad de obsidiana de la Pampa del Asador (Provincia de Santa Cruz). Intersecciones en Antropología, 7: 27-36. (in Spanish) ("East of the Cerro Pampa: enlargement of the obsidian availability area from Pampa Del Asador (Santa Cruz Province)") 
Binford, L. R. 1979, Organization and formation processes: looking at curated technologies. Journal of Anthropology Research, 35: 255-273. doi:10.1086/jar.35.3.3629902

Borrero, L. A. 2012, La Patagonia cuyana. In Logros y Desafíos. Arqueología y Paleoecología de Cuyo (Gil, A. \& Neme, G., Eds.), Sociedad Argentina de Antropología: p. 282-295. (in Spanish) (“Cuyana Patagonia”).

Charlin, J. 2009, Aprovisionamiento, circulación y explotación de obsidianas durante el Holoceno Tardío en Pali Aike (provincia de Santa Cruz). Relaciones de la Sociedad Argentina de Antropología, XXXIV: 53-73. (in Spanish) ("Provisioning, circulation and exploitation of obsidians during the Late Holocene in Pali Aike (Santa Cruz province)”)

Civalero, M. T. \& Franco, N. V. 2003, Early human occupations in Western Santa Cruz Province, Southernmost South America. Quaternary International, 109-110: 77-86. doi: 10.1016/S1040-6182(02)00204-5

Cueto, M., Frank, A. D. \& Skarbun, F. 2016, The exploitation of obsidian in the Central Plateau of Santa Cruz, Argentina: Results from La Maria and Cerro Tres Tetas and a regional perspective. Journal of Lithic Studies, 3(2): 1-22. doi:10.2218/jls.v3i2.1402

Cueto, M., Frank, A. D. \& Skarbun, F. 2018, Explotación de obsidianas en la meseta central de santa cruz. Estrategias de producción, uso y circulación. Chungara Revista de Antropología Chilena, 50(2): 235-253. (in Spanish) ("Exploitation of obsidians in the central plateau of Santa Cruz. Production, use and circulation strategies") doi:10.4067/S0717-73562018005000502

Durán, V., Gil, A., Neme, G. \& Gasco, A. 2003, El Verano: ocupaciones de 8900 años en la Cueva 1 (Santa Cruz, Argentina). In Arqueología y Paleoambiente en la Patagonia Santacruceña Argentina (Aguerre, A. M., Ed.), Ediciones del Autor, Buenos Aires: p. 93120. (in Spanish) ("El Verano: 8900 occupations years in Cave 1 (Santa Cruz, Argentina")

Espinosa, S. L. \& Goñi, R. 1999, ¡Viven!: una fuente de obsidiana en la provincia de Santa Cruz. In: Soplando en el viento... Actas de las Terceras Jornadas de Arqueología de la Patagonia (Goñi, R., Ed.), Instituto Nacional de Antropología y Pensamiento Latinoamericano y Universidad Nacional del Comahue, Neuquén-Buenos Aires: p. 177188. (in Spanish) (“Alive! An obsidian source in the province of Santa Cruz")

Franco, N. V. 2014, Lithic artifacts and the information about human utilization of large areas. In Artefactos líticos, movilidad y funcionalidad de sitios: problemas y perspectivas (Escola, P. \& Hocsman, S., Eds.), Archaeopress, Oxford. BAR International Series 26-28: p. 116127.

Franco, N. V., Brook, G. A., Cirigliano, N. A., Stern, C. \& Vetrisano, L. 2017, 17 de Marzo (Santa Cruz, Argentina): a new distal source of Pampa del Asador type black obsidian and its implications for understanding hunter-gatherer behavior in Patagonia. Journal of Archaeological Science: Report, 12: 232-243. doi:10.1016/j.jasrep.2017.01.037

Gómez Otero, J. \& Stern, C. 2005, Circulación, intercambio y uso de obsidianas en la costa de la provincia del Chubut (Patagonia Argentina), durante el Holoceno tardío. Intersecciones en antropología, 6: 93-108. (in Spanish) ("Circulation, exchange and use of obsidian on the coast of the province of Chubut (Patagonia Argentina), during the late Holocene")

Hammond, H. 2015, Sitios concheros en la costa norte de Santa Cruz: su estructura arqueológica y variabilidad espacial en cazadores recolectores Patagónicos. Doctoral thesis at the Facultad de Ciencias Naturales y Museo, Universidad Nacional de La Plata, La Plata, 618 p. (in Spanish) ("Shell middens in the north coast of Santa Cruz: its archaeological structure and spatial variability in Patagonian hunter gatherers”)

Hermo, D. 2008, Los cambios en la circulación de las materias primas líticas en ambientes mesetarios de Patagonia. Doctoral thesis at the Facultad de Ciencias Naturales y Museo, Universidad Nacional de La Plata, La Plata, 457 p. (in Spanish) ("Changes in the circulation of lithic raw materials in plateau patagonian environments”) 
Hermo, D. 2014, Diseño instrumental y disponibilidad de materias primas. Buscando relaciones en la Meseta Central de Santa Cruz, Argentina. In Artefactos líticos, movilidad y funcionalidad de sitios: problemas y perspectivas (Escola, P. \& Hocsman, S., Eds.), Archaeopress, Oxford. BAR International Series 26-28: p. 106-115. (in Spanish) ("Instrumental design and availability of raw materials. Looking for relationships in the Central Plateau of Santa Cruz, Argentina”)

Hermo, D. \& Miotti, L. 2011, La obsidiana en el Nesocratón del Deseado (Santa Cruz, Argentina): extractos de una oscura biografía. In Biografías de Paisajes y Seres: Visiones desde la Arqueología Sudamericana, (Hermo, D. \& Miotti, L., Eds.). Encuentro grupo Editor. Facultad de Humanidades de Catamarca: p.111-131. (in Spanish) ("Obsidian in the Nesocratón del Deseado (Santa Cruz, Argentina): excerpts from a dark biography”)

Kelly, R. 2011, Obsidian in the Carson Desert: Mobility or Trade? In Investigating Prehistoric Trade and Exchange in Western North America (Hughes, R., Ed.), University of Utah Press, Salt Lake City: p. 189-200.

Meltzer, D. 1989, Was stone exchange among eastern North American paleoindians? In Eastern paleoindian lithic resource use (Ellis, C. \& Lothrop, J., Eds.), Boulder, Westview Press: p. 11-39.

Méndez, C., Stern, C. R., Nuevo Delaunay, A., Reyes, O., Gutiérrez, F. \& Mena, F. 2018, Spatial and temporal distributions of exotic and local obsidians in Central Western Patagonia, southernmost South America. Quaternary International 468: 155-168. doi:10.1016/j.quaint.2017.08.062

Molinari, R. \& Espinosa, S. 1999, Brilla tú, diamante "loco”. In Soplando en el viento. Actas de las III Jornadas de Arqueología de la Patagonia (Belardi, J. B., Fernández, P., Goñi, R. A., Guráieb, G. \& De Nigris, M., Eds.), Instituto Nacional de Antropología y Pensamiento Latinoamericano y Universidad Nacional del Comahue, Neuquén-Buenos Aires: p. 189198. (in Spanish) ("Shine you, "crazy" diamond")

Moreno, E., Zangrando, A. F., Tessone, A., Castro, A. \& Panarello, H. O. 2011, Isótopos estables, fauna y artefactos en el estudio de los cazadores recolectores de la Costa Norte de Santa Cruz. Magallania 39(1): 265-276. (in Spanish) ("Stable isotopes, fauna and artifacts in the study of the hunter gatherers of the North Coast of Santa Cruz")

Nami, H. G. 1992, El subsistema tecnológico de la confección de instrumentos líticos y la explotación de los recursos del ambiente: una nueva vía de aproximación. Shincal, 2: 1353. (In Spanish) ("The technological subsystem of the preparation of lithic instruments and the exploitation of environmental resources: a new approach")

Nami, H., Giesso, M., Castro, A. \& Glascock, M. D. 2017, New analyses of late Holocene obsidians from Southern Patagonia (Santa Cruz province, Argentina). International Association for Obsidian Studies Bulletin, 57: 13-25.

Odell, G. 1996, Economizing behavior and the concept of “curation”. In Stone tools: theoretical insights into human prehistory (Odell, G., Ed.), Plenum Press, New York: p. 51-80.

Pallo, M. C. \& Borrero, L. A. 2015, ¿Intercambio o Movilidad?: Una Evaluación sobre el Uso de Escalas de Análisis Espaciales y Curvas de Declinación en Patagonia Centro-Meridional (Argentina). Latin American Antiquity, 26(3): 287-303. (in Spanish) ("Exchange or mobility?: An evaluation of the use of spatial scales and decline curve analysis in Central Southern Patagonia (Argentina)”). doi:10.7183/1045-6635.26.3.287

Paunero. R., Ambrústolo, P. \& Valiza Davis, C. 2019, Cuenca Inferior del río Deseado: Investigaciones arqueológicas en el sitio Cueva Marsicano, Argentina. In Arqueología de la Patagonia: El pasado en las arenas (Gómez Otero, J., Svoboda, A. \& Banegas, A., Eds.), Instituto de Diversidad y Evolución Austral, Puerto Madryn: p. 421-432. (in Spanish) ("Lower Basin of the Deseado River: Archaeological investigations at the Marsicano Cave site, Argentina”) 
Renfrew, C. 1977, Alternative models for exchange and spatial distribution. In Exchange Systems in Prehistory (Earle, T. \& Ericson, J., Eds.), Academic Press, New York: p. 7189.

Smith, M. S., Lavalley, S. J. \& Wiggins, K. M. 2012, Late Holocene lithic procurement strategies in the northwestern Great Basin: the view from Paiute Creek Shelter, Nevada. North American Archaeologist, 33(4) 399-427. doi:10.2190/NA.33.4.b

Stern, C. R. 1999, Black obsidian from central-south Patagonia: chemical characteristics, sources and regional distribution of artifacts. In Soplando en el viento: Actas de las terceras Jornadas de Arqueología de la Patagonia, (Belardi, J. B., Fernández, P., Goñi, R. A., Guráieb, G. \& De Nigris, M., Eds.), Instituto Nacional de Antropología y Pensamiento Latinoamericano y Universidad Nacional del Comahue, Neuquén-Buenos Aires: p. 221234.

Stern, C. R. 2018, Obsidian sources and distribution in Patagonia, southernmost South America. Quaternary International, 468: 190-205. doi:10.1016/j.quaint.2017.07.030

Zilio, L., Tessone, A. \& Hammond, H. 2018, Stable isotope ecology and human palaeodiet in the northern coast of Santa Cruz (Argentine Patagonia). International Journal of Osteoarchaeology, 28(3): 305-317. doi:10.1002/oa.2655

Zubimendi, M. A. 2019, Cambios y continuidades a lo largo del Holoceno en el uso humano de la Localidad Arqueológica Punta Medanosa (Patagonia Argentina). Relaciones de la Sociedad Argentina de Antropología, XLIV: 107-129. (in Spanish) ("Changes and continuities throughout the Holocene in the human use of the Archaeological Site Punta Medanosa”)

Zubimendi, M. A. \& Ambrústolo, P. 2011, La presencia de ítems marinos en el interior de la Patagonia central. In Movilidad y Migraciones (Ariel Guiance, Ed.), Editorial Dunken, Buenos Aires: p. 291-308. (in Spanish) ("The presence of marine items inside the central Patagonia”)

Zubimendi, M. A., Ambrústolo, P., Beretta, M., Mazzitelli, L., Ciampagna, L., Hammond, H., Zilio, L., Plischuk, M. \& Castro, A. 2011, Sitio Cueva del Negro: Un caso de aprovechamiento intensivo de los recursos marinos en la Costa Norte de Santa Cruz (Patagonia Argentina). Revista de Estudios Marítimos y Sociales, 4: 51-62. (in Spanish) ("Cueva del Negro Site: A case of intensive use of marine resources on the North Coast of Santa Cruz (Patagonia Argentina)”)

Zubimendi, M. A., Ambrústolo, P., Zilio, L. \& Castro, A. 2015, Continuity and discontinuity in the human use of the north coast of Santa Cruz (Patagonia Argentina) through its radiocarbon record. Quaternary International, 356: 127-146.

doi:10.1016/j.quaint.2014.09.035 


\title{
Estrategias de aprovisionamiento y circulación de obsidiana negra en la costa norte de la provincia de Santa Cruz (Patagonia Argentina): movilidad e interacción humana
}

\author{
Pablo Ambrústolo ${ }^{1}$ \\ 1. CONICET - División Arqueología, Facultad de Ciencias Naturales y Museo, Universidad Nacional de La \\ Plata, Museo de La Plata. Paseo del bosque s/n (1900). La Plata, Argentina. Email: pambrustolo@hotmail.com
}

\section{Resumen:}

En este artículo, evaluamos las estrategias de aprovisionamiento y reducción de obsidiana negra registradas en refugios rocosos y sitios concheros ubicados en la costa norte de la provincia de Santa Cruz, en la Patagonia argentina. Los análisis geoquímicos realizados en artefactos de obsidiana negra de esta área muestran la circulación a larga distancia de esta materia prima identificada en la fuente Pampa del Asador, ubicada aproximadamente a $400 \mathrm{~km}$ al oeste. En un trabajo anterior, propusimos que el registro de evidencias de explotación inicial de guijarros de obsidiana, sumado a la identificación de artefactos con altos porcentajes de corteza, sugeriría que la obtención de piezas de dicha materia prima habría estado bajo morfologías de guijarros. Los resultados de esta presentación refuerzan esa idea, al menos para contextos ocupacionales asignables al Holoceno tardío.

En el Holoceno medio se observa una representación muy baja de productos de talla de tamaño muy pequeño sin reserva cortical, no se registran núcleos ni artefactos formatizados. Se evidencian actividades de talla relacionadas con estadio técnicos intermedios en el marco de la reducción del núcleo y la producción en nódulos, probablemente con tamaños pequeños o muy pequeños, y preformas bifaciales. Se infiere el probable ingreso a los sitios de piezas como parte de equipos de herramientas personales, núcleos y artefactos bifaciales sin corteza, en el marco de los momentos de exploración.

Para las ocupaciones del Holoceno tardío, en función del hallazgo de guijarros de obsidiana que poseen dimensiones similares a las registradas en la propia fuente, interpretamos que su adquisición se habría producido a través de varios mecanismos vinculados, entre otros factores, con el establecimiento y fortalecimiento de relaciones sociales en el marco de circuitos de movilidad que unirían la costa y el interior.

Keywords: obsidiana; aprovisionamiento; explotación; cazadores-recolectores; movilidad humana; Patagonia 